\title{
Maritime Transport Services in ASEAN-China Free Trade Area-Liberalization and Challenges
}

\author{
Yan $\mathrm{Lu}^{1}$ \\ ${ }^{1}$ Guangxi Research Institute for Innovation and Development, Guangxi University, Nanning, China \\ Correspondence: Yan Lu, assistant research fellow of Guangxi Research Institute for Innovation and \\ development, Guangxi University, Nanning, China.
}

Received: June 17, 2019

Accepted: September 20, 2019

Online Published: September 20, 2019

doi:10.20849/ajsss.v4i3.634

URL: https://doi.org/10.20849/ajsss.v4i3.634

\begin{abstract}
Maritime transport, as an international transportation, plays an imperative role in global trades. At present, the negotiation on maritime transport sector faces with difficulties. This brief article tries to indicate the challenges of maritime service trade liberalization in CHINA-ASEAN free trade area; to find out the ways to promote maritime trade liberalization.
\end{abstract}

Keywords: maritime transport, liberalization, trade services, ASEAN

\section{Introduction}

At a very early age, the Association of Southeast Asian Nations (hereinafter referred to ASEAN) and China have been connected and interacted with each other. When did the maritime trade happened? When did the maritime trade happen between Association of Southeast Asian Nations (hereinafter referred to ASEAN) and China? At a very early age, ASEAN and China had been connected and interacted with each other. (Note 1) Han State began to interact with South Asian nations when Chinese military arrives in West (Pearl) River Delta in B.C.111, which is northern Vietnam today (Note 2). As James Chin discusses in his chapter, a range of coastal trading centers developed along the coast that connect Guang-dong and northern Vietnam (Note 3). Since that time, maritime trade was booming between Southeast Asia and China (Note 4). Over two thousand years, the trade relationship is more prosperous between ASEAN and China. ASEAN was founded by Malaysia, Philippines and Thailand on July 31, 1961 in Bangkok which named Association of Southeast Asia (Note 5). On August 8, 1967, the Foreign Minister of Indonesia, Thailand, Singapore, Philippines and Vice Prime Minister of Malaysia held the meeting in Bangkok (Note 6). The "Association of Southeast Asian Nation Declaration", namely the "Bangkok Declaration" was published, since then ASEAN was established officially (Note 7). From the 1980s to 1990s, Brunei (1984), Vietnam (1995), Laos (1997), Myanmar (1997) and Cambodia (1999) successively joined the organization, making ASEAN from five members expanded to 10 members (Note 8). However, ASEAN internal cooperation cannot fundamentally change the condition which is ASEAN internal market relatively small and too many similar industries. In order to seek more extensive cooperation in Asia, ASEAN pursue the mode of "ASEAN+X". On November 6, 2001, China and ASEAN countries leaders at the fifth meeting reached important agreement: both sides established ASEAN-China Free Trade Area (hereinafter referred to ACFTA) in ten years. (Note 9) ACFTA is one of the world's three major regional economic zone as well as the third biggest free trade area in the world (Note 10). As ACFTA was officially launched on the January 1, 2010, bilateral trade between China and ASEAN continues to expand and strengthen (Note 11). China and ASEAN are linked by mountains and rivers, taking the waters of the Beibu Gulf and the South China Sea at the center, including the international ports and over 100 types of major ports group that situated in China and the ASEAN countries (Note 12). Since trade have increased between China and ASEAN countries, maritime trade or port trade was taking up the whole of China and ASEAN trade over 90\% (Note 13). Because shipping has its advantages which are low-cost, large-capacity, it frequently becomes the first choice of the mode of transport for international trade in goods. The more maritime transport existed between China and ASEAN, the more maritime services need to be provided, so ASEAN-China could not only focuses on the port infrastructure but also pays attention to the infrastructure construction, such as maritime transport services cooperation in ACFTA.

Due to frequent maritime trade between ASEAN and China, China and ASEAN countries are need to open their borders and progressively liberalize maritime transport services. Striving for mutual benefits and common 
prosperity, the ASEAN-China shall focus on regional economy and trade cooperation. Furthermore, it shall provide a good investment and legal environment for foreign investors. ACFTA also combines with the characteristics of own development and learns the regulation of the maritime transport services from other FTA (e.g. ASEAN Free Trade Area) (Note 14). Because most of the ACFTA members are developing country, they are not very powerful in maritime transport sector from the traditional perspective. However, ACFTA provides a challenge also an opportunity for the member countries to promote their shipping industry. On the other hand, it will bring effective competition to these nations.

The prosperity of maritime trade cannot without complete legal regulation, lacking the law will result in hamper the development of regional trade and trade in service. The major rule regulate service in ACFTA is the ASEAN-China "Service Trade Agreement". However, as the ASEAN-China is a regional economic integration organization under World Trade Organization, it should also abide by the GATS.

\section{The Challenges in Maritime Transport Services Between ASEAN and CHINA}

\subsection{International Background}

After World War II, international trade, finance and investment have developed quickly, economic ties between countries all over the world is becoming more closely than before. Meanwhile, multilateral trading system have made new progress which provided institutional infrastructure for booming development of economic globalization.

Maritime transport service which has a close relationship with trade in goods plays an important role in international services trade. The rapid growth of trade in goods promote the related international transportation services development, such as international freight forwarding business, port services and auxiliary services. On the contrary, maritime transport services will further facilitate trade in goods. It encourages that foreign investors and private capital participate in the operation of port services which relate to maritime transport services. Demanding trade in services between China and ASEAN still keep rising. From the development of each member domestic economic perspective, China and ASEAN countries are facing the challenge of industrial transformation.

However, the development of service trade between China and ASEAN countries are seriously lagging behind trade in goods. In the first half of this year, ASEAN surpassed the U.S. as China's second-largest cargo trading partner, according to import and export data released by the general administration of customs. In the first half of this year, the total value of China's imports and exports to ASEAN was US \$291.85 billion, up 4.2\% year-on-year, accounting for $13.5 \%$ of China's total value of imports and exports (Note 15). Among ASEAN countries, the total value of goods trade between Vietnam and China ranks first, with 69.93 billion US dollars, followed by Malaysia, Thailand, Singapore and Indonesia (Note 16). Ports play an important role in world import and export trade. With the development of "One Belt and One Road", encouraging progress has been made in cooperation between China and ASEAN countries in such areas as infrastructure, customs clearance, port and shipping logistics and port-adjacent industrial parks. The "One Belt And One Road" initiative has encouraged more and more Chinese enterprises to invest in overseas ports, including the construction and operation of docks and port-adjacent industrial parks. More and more ASEAN enterprises are also coming to China to jointly build ports, open new shipping routes and build logistics parks.

Based on the advantages of geographical, cultural and realistic basis for cooperation, the bilateral will bring to each other more conveniences. With the development of ACFTA, trade in goods between both sides have developed rapidly and foreign direct investment have become increasingly active. Then further increase transportation demand for services such as transportation, especially maritime transport services bring more opportunities to service providers.

\subsection{The Negotiation of Maritime Transport Service in CHINA and ASEAN}

In January 2007, China and ASEAN signed free trade service trade agreement, implemented in July 2007. (Note 17) China and ASEAN countries respectively in the form of schedule lists each specific commitment to open services sector. China has made four commitments (Note 18). The first one is international transport (Note 19). China's commitments starting from the accession to the WTO, includes passenger and freight transport which allow foreign ships affiliated to China liner shipping company (Note 20). The company is engage in operating a fleet and flying the Chinese flag to allow foreign suppliers to establish joint venture shipping company in China (Note 21). Furthermore, proportion of foreign investment shall not exceed $49 \%$ and the foreign suppliers shall not operate coastal shipping and inland waterway transport (Note 22). The second one is maritime service (Note 23). It allows not only establishing joint ventures in the area of shipping agency that in charge of load and unload, 
container storage station, take over and storage, but also foreign enterprises holdings to operate shipping business (Note 24). Shipping agent business only allowed set up joint ventures, besides foreign investment ratio does not exceed $49 \%$ (Note 25). Warehousing freight forwarding can be sole proprietorship (Note 26). The third one is using port services without discrimination and the fourth is to apply for MFN duty exemption (Note 27).

In Singapore, international maritime transport services (freight and passenger) which not include coastal transport have been opened (Note 28). Maritime auxiliary contains international towing and classification society (Note 29). Maritime service delivery is no limit (Note 30). The open sectors contain the cross-border supply, consumption abroad and commercial presence of trade restrictions on national treatment (Note 31). The national treatment for the movement of natural persons is unbound (Note 32).

Open sector in Malaysia is maritime auxiliary services (Note 33). Market access for commercial presence is limited to provide office and regional office in Malaysia (Note 34). Malaysian citizen or holding company established a joint venture with a local joint venture to provide services, but the total foreign equity joint venture cannot exceed $49 \%$ (Note 35). There is no limit on the national treatment (Note 36).

The liner shipping in the Philippines is regulated by Decree No. 806 of their country (Note 37). The preferential cargo sharing arrangements is to ensure the effective participate in national liner trades in goods (Note 38).

Open sector in Vietnam is international shipping services (Note 39). The passenger transport and freight transport, which include small amount of coastal transport, containers handling services, clearance service and container yard heap services (Note 40).

These departments have no commitment on cross-border delivery and restrictions on consumption abroad (Note 41).

Market access for transport goods abide by the following limits (Note 42). When the agreement enters into force, it allows foreign providers set up joint ventures, but the proportion of foreign investment cannot exceed $49 \%$ (Note 43). Allowing joint venture owned Vietnamese nationality of vessels and flying the employment of foreign crews, but it cannot exceed one-third of the total number of foreign crews (Note 44). Master or chief mate must be Vietnamese citizens (Note 45). Commercial presence for container handling services were limited, it allows foreign joint ventures, but the proportion of foreign investment cannot exceed $50 \%$ (Note 46). The customs clearance services in commercial presence were limited, which only allow foreign joint ventures (Note 47). However, the proportion of foreign investment cannot exceed $51 \%$ until the agreement came into effect in five years (Note 48). Container field heap services have done the same restrictions, but time is seven years after entry into force of the agreement (Note 49). The national treatment for consumption abroad and commercial presence is no limit (Note 50).

Open sector in Brunei is passenger transport and freight transport (Note 51). In market access for cross-border consumption, there is no restriction on consumption abroad and commercial presence (Note 52). It is unbound for national treatment on the cross-border consumption, trade restrictions on consumption abroad and commercial presence (Note 53).

According to the second package of Agreement on Trade in Services, there are 9 ACFTA members who have made commitments in international maritime transport. All of the 9 members contain both passenger and freight services (Note 54). Only Cambodia is unbound to these commitments and Lao have not made any commitments on international shipping services yet (Note 55). The majority of restrictions include "nationality requirements for ownership" (Note 56) and registration of ships under certain national flag. The percentage of joint venture requires "discriminatory taxation and discriminatory port charges" (Note 57) There are nine member states have scheduled commitments in auxiliary services, which are maritime cargo handling services, rental of vessel without crew, rental/leasing services of seagoing vessels with operator for international shipping, maritime agency services covering marketing and sales of maritime transport and related services, vessel salvage and refloating services, maritime freight forwarding services, storage and warehousing services, maritime cargo handling services, maintenance and repair of vessels, shipping brokerage services, classification societies, supporting services for maritime transport shore reception facilities and customs clearance services (Note 58). Nine member states also have made commitments on port services, for instance, international towage, port captain's services and container station and deport (Note 59). The six member states have scheduled additional commitments relating to international maritime transport suppliers on reasonable and non-discriminatory terms and conditions (Note 60). The rest of states who are Myanmar, Philippines, Thailand, Brunei Darussalam and Lao PDR had not made additional commitments (Note 61). 
As far as maritime transport is concerned, the openness extent in China is higher than ASEAN countries (Note 62). Though other countries made commitments in varying degrees, the open sector is little and open level is still very low. The differences between countries and sectors are relatively large. The ASEAN countries are still exists in a large of trade protection policies which will affect the progress of liberalization on maritime services in the ASEAN.

In October 2003, the $2^{\text {nd }}$ ASEAN-China Transport Ministers Meeting held in Rangoon, Burma (Note 63). Chinese Ministry of Transport initially proposed setting up the maritime consultation mechanism, which attained supports from ASEAN countries (Note 64). Maritime consultation mechanism provides a good platform for China and ASEAN to discuss maritime transport services related to how liberalize maritime transport services. China maintains good ties with ASEAN countries in the area of maritime transport cooperation and signs maritime agreements with most of ASEAN countries (Note 65). It is worth noting that the majority of agreements have been well performed. Based on the schedule of arrangement, both parties have close cooperation in utilization of port facilities and merchant shipping. Vessels of Chinese shipping companies call at ports of most ASEAN countries and some of Chinese shipping companies have established their local branches or representative offices there for conduct shipping businesses. The measures mentioned above has contributed to ASEAN-China economic and trade development.

With further opening up China's international shipping market, foreign shipping companies including those in ASEAN countries can gain more commercial benefits in China. Both sides have been actively coordinated with each other for mutual support in safeguarding navigational safety at sea, promoting marine environment protection and have made positive contributions.

\subsection{Cabotage Policies in Shipping Services}

To reserve national coastal and inter-island shipping services, entirely excluding or at least restrict foreign operator from access into domestic coastline by every country's regulations that are termed cabotage policy (Note 66). Cabotage policies have a significant impact on country whose coastline is long, such as China, Indonesia, Malaysia, Myanmar, Philippines, Thailand, Vietnam (Note 67). However, the country whose coastline is short, for instance, Singapore, Cambodia, Brunei and Lao PDR, and their cabotage policies may not be so important (Note 68).

The cabotage policy in China has been stated in the Maritime Code of the People's Republic of China, which came into effect on 1 July 1993 (Note 69). In according to the Article 4 states that "maritime transport and towage services between the ports of the People's Republic of China shall be undertaken by ships flying the national flag of the People's Republic of China, except as otherwise provided for by laws or administrative rules and regulations". (Note 70) It could be seen that cabotage trade is only allowed national vessels to operate, because most of the countries are seriously concern about national security, economic issues and other essential problems. The regulation of Waterway Transport Administration of the People's Republic of China came into effect on 1 January 2013 (Note 71). The article 11 of the regulation also states that "foreign enterprises, other economic organization or individual may not engage in the business of water transportation, and it should not be disguised in Chinese vessels of rent or space to do water transportation business" (Note 72).

Cabotage policy in Indonesia before 2005 is not so important, because the policy does not turn into effect in practical when it reserves domestic cargo for Indonesian ship owners and flagged vessels (Note 73). Because shipping is a high standard industry and majority of Indonesian companies cannot fulfill it, so foreign companies and foreign vessels account for the main sea transportation in Indonesia (Note 74). Therefore, the Indonesian government has announced the cabotage principle in order to protect and prosper national shipping industries (Note 75). The cabotage principle is based on Maritime Law and Presidential Instruction No.5 of 2005 which concerning the empowerment of the shipping industries (Note 76). Article 8 of Indonesia Shipping Law states that "sea activities in the country shall be convened by the national sea transport companies, organizers of the special marine transportation and shipping companies use the Indonesia flagged ship and by Indonesia crews." (Note 77) In other words, Indonesia Shipping Law provides that domestic sea transportation shall be carried out by national shipping companies, by Indonesian flagged vessels and by an Indonesian crew. Similarly, a foreign vessel is prohibited from transporting passengers and/or goods between islands or ports in Indonesian territory. Further, article 341 of the Shipping Law requires that the cabotage principle to be fully applied in three years (i.e. by May 7, 2011) (Note 78). The Indonesia Shipping Law has included a very significant cabotage requirements which formally requires that all foreign-flag vessels operating in the Indonesian domestic trades should be replaced by (or re-registered as) Indonesian flag vessels and Indonesian crews (Note 79). 
The objective of cabotage policy is to develop Malaysian merchant fleets and domestic shipping companies also decrease Malaysia's dependence on foreign vessels (Note 80). Cabotage policy in Malaysia allows foreign-flagged vessels attain license by the Domestic Shipping and Licensing Board (DLSB) (Note 81). The Maritime Division of the Ministry of Transport is to operate coastal trading and transport cargoes when the domestic ships have no available (Note 82). Malaysia intends to relax cabotage policy in order to "allow foreign lines to carry transshipment cargo between designated ports in East Malaysia(Sabah, Sarawak) and Port Klang in 2000" (Note 83). Actually, the cabotage policy does not entirely ban vessels from foreign ports to call directly to/from any Malaysian port, which including ports in Sabah and Sarawak. For instance, a vessel from Singapore or Hong Kong is free to call directly to/from any Malaysian port such as Sepanggar, Bintulu etc. (Note 84). Though Malaysia has cabotage policy, it implements relative liberal policy because Malaysia also permits foreign vessels enter into or carry on business within their domestic shipping market as long as foreign operators get the permission from the Domestic Licensing Board (Note 85). Recently, there are growing calls that is to abolish cabotage policy in Malaysia, because foreign ships usually directly access Malaysian ports with cargoes (Note 86).

Myanmar remains coastal cargoes transported by domestic flag vessels (Note 87).

In the Philippines, the domestic vessels are protected by cabotage rule. Though there are some relaxations on cabotage policy, foreign flag vessels allowed call at one Philippine port (Note 88). As far as government cargoes are concerned, they should be transported only by Philippine registered ships in accordance with the PD 1466 (Note 89). Foreign lines can be used when the domestic operators cannot meet the requirements. Philippine Shippers' Bureau is the executive department of PD 1466 which "requires that all government cargoes and those cargoes owned by private entities with government loan, credits and guarantees be loaded on RP-flag vessel, otherwise, a waiver must be secured from PSB whenever such vessels are not available and/or suitable" (Note 90).

Coastal line transportation reserved for Thai flag vessels in Thailand (Note 91). In accordance with Thailand Vessel Act, B.E.2481 Section 7 bis, it states that limited company or public limited company has no less than $70 \%$ of company's registered capital shares owned by a non-foreigner (Note 92). It means foreigners own up to 30\% of Thai equity for engaging in trade in Thai waters (Note 93). Domestic shipping transportation requires that the ship must be possessed either by a natural person of Thai nationality or ordinary partnership (Note 94). All partners must be natural persons or state enterprise of Thai nationality under Thai law (Note 95). If there is no available Thai vessel used, applicant may apply permission from the Ministry of Transport for employing a foreign flag vessel (Note 96).

Foreign vessels are not allowed entry into Vietnamese waters, and there is "full cabotage": $100 \%$ by Vietnamese flag vessels (Note 97). If there are some special causes, foreign vessels should get the permission or approval from the Minister of Transport (Note 98).

\section{The common Maritime Transport Polices in Future}

The suggestions for the future development of maritime transport policy requests that members of the parties respect the ASEAN countries and Chinese history. Common maritime policy which needs to fit for the regional trade development. Since maritime transport cooperation among ASEAN countries and China, the both parties have established negotiation mechanism and the bilateral agreement (Note 99). The negotiation and consultation mechanism are effective platforms provided for both the parties to discuss the maritime transport issues and safeguard their own maritime interest.

Establishing common maritime transport principle, for instance, non-discriminatory access to cargoes, transparency principle, free and fair competition, progressive opening up cabotage trade, and further liberalization of specific commitment. These efforts intend to build a series of common maritime principles to request member states to abide by the rules, and then remove the obstacles which hinder the maritime transport liberalization.

The regulation of maritime transport in ACFTA has its characteristics. The negotiation and consultation mechanism will facilitate the integration of maritime transport services among ACFTA member states. ACFTA also provides a platform for member states to communicate with each other on this sector.

\section{Conclusion}

After more than 20 years of development, the friendship, mutual trust and cooperation between ASEAN and China have been continuously deepened. In accordance with the design of the ACFTA "framework agreement", progressive liberalization of trade in services covering a wide range of sectors that is an important content of the 
target of ACFTA. However, because there is competition in trade in services between China and ASEAN, many legal obstacles within trade in services liberalization which is bound to affect the ACFTA trade liberalization process. Overall, due to the rising status of China and China's entry into the WTO, China's rising expectations that more requests in open market. The economic strength of Individual ASEAN countries small than China, but ASEAN as a whole, in ACFTA system, can compete with China. In addition, for China and ASEAN countries, there is a contradiction to expand the opening up of service and safeguard national economic security. This is indeed a great challenge for developing countries. The legal system of ACFTA service trade should proceed from the economic realities of China and ASEAN countries. The object is to respect different interests between ASEAN and China, instead of blindly seek common ground on the market openness and speed.

\section{References}

Farthing, B., \& Brownrigg, M. (1997). Farthing on international shipping (3rd ed.), p101. London,Hong Kong, LLP.

Gu, X. S., Li, M. J., \& Gulf, B. (2009, January 2). Emerging sub-regional integration between China and ASEAN. Retrieved from https://dr.ntu.edu.sg/bitstream/handle/10220/4550/WP168.pdf?sequence=1

Lun, Y. H. V., Lai, K.-H., \& Cheng, T. C. E. (2010). Shipping and Logistics Management, p. 6. London: Springer.

Seong, M. L. (n.d.). International Program, "ASEAN: brief history and its problems". Retrieved from http://www.zum.de/whkmla/sp/0607/seongmin/seongmin.html

Wade, G. (2009). China and Southeast ASIA-Volume 1: Introduction and history to the fourteenth century (1st ed.), pp. 1-4. Routledge, Oxon.

Yan, J. (2010). On Several Important Aspects of the History of Culture Exchanges between China and Southeast Asia. Around Southeast Asia, (1), 83.

\section{Notes}

Note 1. See Geoff Wade, China and Southeast ASIA-Volume 1: Introduction and history to the fourteenth century, 1st edition, Routledge, Oxon, 2009, pp. 1-4.

Note 2. Ibid., Yan Jie, On Several Important Aspects of the History of Culture Exchanges between China and Southeast Asia, AROUND SOUTHEAST ASIA, 2010(1),p 83.

Note 3. Ibid.

Note 4. Ibid.

Note 5. See Seong Min Lee, International Program, "ASEAN: brief history and its problems", available at $<$ http://www.zum.de/whkmla/sp/0607/seongmin/seongmin.html $>$.

Note 6. See History-The Founding of ASEAN, available at $<$ http://www.asean.org/asean/about-asean/history $>$.

Note 7. See The ASEAN Declaration (Bangkok Declaration) Bangkok, available at < http://www.asean.org/news/item/the-asean-declaration-bangkok-declaration>.

Note 8. See XinHua NEWS, "Association of Southeast Asia Nations", available at $<$ http://news.xinhuanet.com/ziliao/2002-10/28/content_610510.htm>.

Note 9. See ASEAN-China Dialogue Relations, available at $<\mathrm{http}: / /$ www.asean.org/news/item/asean-china-dialogue-relations $>$.

Note 10. Ibid.

Note 11. Ibid.

Note 12. See Gu Xiaosong, Li Mingjiang, Beibu Gulf: emerging sub-regional integration between China and $\begin{array}{lllll}\text { ASEAN, } & 2 & \text { January } & \text { available }\end{array}$ at $<$ https://dr.ntu.edu.sg/bitstream/handle/10220/4550/WP168.pdf?sequence=1>.

Note 13. See Y.H.V. Lun, K.-H.Lai, T.C.E. Cheng, Shipping and Logistics Management, London, Springer, 2010, p 6.

Note 14. See ASEAN Free Trade Area( AFTA Council), available at < http://www.asean.org/communities/asean-economic-community/category/asean-free-trade-area-afta-council>.

Note 15. See In the first half of this year, the trade volume between China and asean reached us $\$ 291.85$ billion, 
up 4.2\% year on year, available at $<$ https://finance.sina.com.cn/roll/2019-07-31/doc-ihytcerm7506919.shtml>.

Note 16. see Asean has surpassed the United States as China's second largest trading partner, available $\mathrm{at}<\mathrm{http}: / /$ www.caexpo.org/index.php? $\mathrm{m}=$ content $\& \mathrm{c}=$ index $\& \mathrm{a}=$ show\&catid=420\&id=236218>.

Note 17. China-ASEAN Free Trade Area, available at: $<$ http://www.cafta.org.cn/>.

Note 18. See CHINA-SCHEDULE OF SPECIFIC COMMITMENTS, AC-TIS/SC2/PRC, For the 2nd Package of Commitments under ASEAN-China FTA Trade in Services, pp. 52-54.

Note 19. Ibid.

Note 20. Ibid.

Note 21. Ibid.

Note 22. See CHINA-SCHEDULE OF SPECIFIC COMMITMENTS, For the 2nd Package of Commitments under ASEAN-China FTA Trade in Services.

Note 23. Ibid.

Note 24. Ibid.

Note 25. Ibid.

Note 26. Ibid.

Note 27. Ibid.

Note 28. Ibid.

Note 29. Ibid.

Note 30. Ibid.

Note 31. Ibid.

Note 32. Ibid.

Note 33. See MALAYSIA-SCHEDULE OF SPECIFIC COMMITMENTS, For the 2nd Package of Commitments under ASEAN-China FTA Trade in Services.

Note 34. Ibid.

Note 35. Ibid.

Note 36. Ibid.

Note 37. See Presidential Decree No.806, s.1975, available at $<$ http://laws.chanrobles.com/presidentialdecrees/9_presidentialdecrees.php?id=833>

Note 38. See Fabien BERTHO, Preferential Agreements in Maritime Transport The current and the outdated, available at $<$ http://www.ecipe.org/media/publication_pdfs/Bertho_PrefAinMaritime.pdf $>$.

Note 39. See VIETNAM-SCHEDULE OF SPECIFIC COMMITMENTS, For the 2nd Package of Commitments under ASEAN-China FTA Trade in Services.

Note 40. Ibid.

Note 41. Ibid.

Note 42. Ibid.

Note 43. Ibid.

Note 44. Ibid.

Note 45. Ibid.

Note 46. Ibid.

Note 47. Ibid.

Note 48. Ibid.

Note 49. See VIETNAM-SCHEDULE OF SPECIFIC COMMITMENTS, For the 2nd Package of Commitments under ASEAN-China FTA Trade in Services.

Note 50. Ibid. 
Note 51. See BRUNEI DARUSSALAM-SCHEDULE OF SPECIFIC COMMITMENTS, For the 2nd Package of Commitments under ASEAN-China FTA Trade in Services.

Note 52. Ibid.

Note 53. Ibid.

Note 54. See SCHEDULE OF SPECIFIC COMMITMENTS, the 2nd Package of Commitments under ASEAN-China FTA Trade in Services.

Note 55. See Cambodia-SCHEDULE OF SPECIFIC COMMITMENTS, For the 2nd Package of Commitments under ASEAN-China FTA Trade in Services.

Note 56. WTO Doc. No. S/C/W/62, 16 November 1998.

Note 57. Ibid.

Note 58. See Second Package of Agreement on Trade in Services of ACFTA.

Note 59. Ibid.

Note 60. Ibid.

Note 61. Ibid.

Note 62. Ibid.

Note 63. See ASEAN-CHINA DIALOGUE RELATIONS, available at < http://www.asean.org/asean/external-relations/china/item/asean-china-dialogue-relations>

Note 64. See China-ASEAN Maritime Consultation Mechanism Meeting, available at $<$ http://eng.caexpo.org/newscenter/activities/7th/MaritimeConsultation/hynews/t20101015_90295.html>.

Note 65. See Agreement on maritime transport between ASEAN and China.

Note 66. See Bruce Farthing and Mark Brownrigg, Farthing on international shipping, Third Edition, London, Hong Kong, LLP,(1997), p101.

Note 67. See PDP Australia Pty Ltd/Meyrick and Associates, Promoting Efficient and Competitive Intra-ASEAN Shipping Services, pp 28-29.

Note 68. Ibid.

Note 69. See Maritime Code of The People's Republic of China.

Note 70. Ibid.

Note 71. See Regulation on the Administration of Domestic Water Transport (in Chinese), available at:<athttp://www.gov.cn/zwgk/2012-10/22/content_2248746.htm>.

Note 72. Ibid.

Note 73. See PDP Australia Pty Ltd/Meyrick and Associates, Promoting Efficient and Competitive Intra-ASEAN Shipping Services-Final Report, pp. 28-9.

Note 74. See PDP Australia Pty Ltd/Meyrick and Associates, Promoting Efficient and Competitive Intra-ASEAN Shipping Services-Indonesia Report, pp. 2-3.

Note 75. Ibid.

Note 76. See 2011 Indonesian Law Review: Shipping, available at $<$ http://blog.ssek.com/index.php/2012/01/2011-indonesian-law-review-shipping/>.

Note 77. See Indonesia Shipping Law No.17/2008, article 8.

Note 78. See 2011 Indonesian Law Review: Shipping, available at $<$ http://blog.ssek.com/index.php/2012/01/2011-indonesian-law-review-shipping/>.

Note 79. See Indonesia Shipping Law No.17/2008.

Note 80. See PDP Australia Pty Ltd/ Meyrick and Associates,Promoting Efficient and Competitive Intra-ASEAN Shipping Services-Malaysia Country Report, p 3.

Note 81. See The National Maritime, Malaysia, available at: http://www.portsworld.com/law/fpage3.htm.

Note 82. See PDP Australia Pty Ltd/ Meyrick and Associates,Promoting Efficient and Competitive Intra-ASEAN Shipping Services-Malaysia Country Report, p 3. 
Note 83. Ibid.

Note 84 . See Cabotage policy will be reviewed, available at: $<$ http://www.malaysiakini.com/letters/101051>

Note 85. See PDP Australia Pty Ltd/ Meyrick and Associates,Promoting Efficient and Competitive Intra-ASEAN Shipping Services-Malaysia Country Report, p. 3.

Note 86. Ibid, p 4.

Note 87. See PDP Australia Pty Ltd/Meyrick and Associates, Promoting Efficient and Competitive Intra-ASEAN Shipping Services-Final Report, $\mathrm{p} 28$.

Note 88. See PDP Australia Pty Ltd/ Meyrick and Associates,Promoting Efficient and Competitive Intra-ASEAN Shipping Services-The Philippine Country Report, p 3.

Note $89 . \quad$ See PRESIDENTIAL DECREE No.1466, available at<http://www.lawphil.net/statutes/presdecs/pd1978/pd_1466_1978.html>.

Note 90. See Philippine Shippers' Bureau, available at <http://www.dti.gov.ph/dti/index.php?p=177>.

Note 91. See PDP Australia Pty Ltd/Meyrick and Associates, Promoting Efficient and Competitive Intra-ASEAN Shipping Services-Main Report, p 29.

Note 92. See THAI VESSELS ACT,B.E.2481, available at < http://thailaws.com/law/t_laws/tlaw0425.pdf $>$.

Note 93. Ibid.

Note 94. See PDP Australia Pty Ltd/Meyrick and Associates, Promoting Efficient and Competitive Intra-ASEAN Shipping Services-Thailand Country Report, $\mathrm{p} 3$.

Note 95. Ibid.

Note 96. Ibid.

Note 97. See PDP Australia Pty Ltd/Meyrick and Associates, Promoting Efficient and Competitive Intra-ASEAN Shipping Services-Vietnam Country Report, pp. 4-5.

Note 98. Ibid.

Note 99. Maritime Consultation Mechanism Meeting, ASEAN-China Trade in Services and Agreement on maritime transport between ASEAN and China.

\section{Copyrights}

Copyright for this article is retained by the author(s), with first publication rights granted to the journal.

This is an open-access article distributed under the terms and conditions of the Creative Commons Attribution license (http://creativecommons.org/licenses/by/4.0/). 